This paper is dedicated to the memory of Vladimir Vasilyevich Zherikhin (1945-2001), a paleoentomologist, paleoecologist, and biogeographer whose ideas often were ahead of their time

\title{
On the history of ranges of two relict nematoceran families, Ptychopteridae and Tanyderidae (Insecta: Diptera): a biogeographical puzzle
}

\section{О генезисе ареалов двух реликтовых семейств диинноусых двукрылых Ptychopteridae и Tanyderidae (Insecta: Diptera): биогеографическая загадка}

\author{
Kirill Y. Eskov \& Elena D. Lukashevich \\ К.Ю. Еськов, Е.А. Аукашевич
}

Borissiak Palaeontological Institute, Russian Academy of Sciences, Moscow, Russia. afranius999@gmail.ru, elukashevich@hotmail.com Палеонтологический институт им. А.А.Борисяка РАН, Москва, Россия.

KEY WORDS: palaeobiogeography, Mesozoic, Gondwanaland, fossils, zonal stratification.

КЛЮЧЕВЫЕ СЛОВА: палеобиогеография, мезозой, Гондвана, ископаемые, зональная стратификация.

ABSTRACT. The relict dipteran families Ptychopteridae and Tanyderidae, both dating to the Mesozoic, have similar known fossil records but surprisingly dissimilar modern ranges. The difference is hard to interpret by considering the Mesozoic and Early Cenozoic plate tectonics alone. Climatic and ecosystem changes during the Early Paleogene (shifting from an equable to a zonal global climate) combined with extinction throughout most of the original range played a greater role in shaping these ranges than plate tectonics.

РЕЗЮМЕ. Ptychopteridae и Tanyderidae - peликтовые семейства двукрылых мезозойского возраста, имеющие весьма сходную палеонтологическую историю, но резко различное современное распространение. Различия эти довольно трудно интерпретировать только с точки зрения палеогеографии мезозоя и раннего кайнозоя. Судя по всему, гораздо большую роль, чем тектоника плит, сыграли ландшафтно-климатические перестройки в раннем палеогене (переход от эквабильного к зональному типу глобального климата) с последующими вымираниями мезозойских реликтов на большей части их былого ареала.

\section{Introduction}

Ptychopteridae and Tanyderidae are ancient, archaic families of nematoceran Diptera and are both important for understanding the early evolution of the order. Originally tanyderids were included within Ptychopteridae but later became recognized as a distinct family [Alexander, 1927]. Some current authors place Pty- chopteridae and Tanyderidae into different infraorders [Krzemiński, Krzemińska, 2003; Yeates et al., 2007; Wiegmann et al., 2011], while others still consider them as members of one infraorder [Wood, Borkent, 1989; Oosterbroek, Courtney, 1995; Shcherbakov et al., 1995; Blagoderov et al., 2007]. In all cases the families are considered to be more or less closely related.

At present, both families are small (Appendices 1, 2): 3 ptychopterid genera include 85 extant species, and 10 tanyderid genera include 38 extant species. Both families enter the fossil record almost simultaneously, prior to the middle Mesozoic, and are relatively well known in the fossil state: nearly 400 imprints (most often as isolated wings) and several inclusions of ptychopterids have been recorded from nearly 40 localities (pers. obs.) starting from the Late Triassic [Barth et al., 2011], fossil tanyderids are not nearly as common and are known since the Early Jurassic [Ansorge, 1994; Skibińska et al., 2014]. So far, there have been described 76 extinct species of Ptychopteridae in 12 genera including one extant genus known since the Early Cretaceous [Kalugina, 1989; Lukashevich, 2008, 2012; Evenhuis, 2015] and 27 extinct species of Tanyderidae in 7 genera including one extant genus, possibly known since the Middle Jurassic [Kalugina, 1992; Lukashevich, Krzemiński, 2009; Dong et al., 2015].

Modern representatives of Ptychopteridae and Tanyderidae are generally similar in their biology, with aquatic larvae feeding on decomposing organic material, and occasionally occur geographically together, e.g. such co-occurrence of Protanyderus vipio (Osten-Sacken, 1877) and Ptychoptera lenis Osten-Sacken, 1877 is recorded near San Francisco in California [Alexander, 
1967]. In spite of the obvious rarity of Tanyderidae they occur on all recent continents except of Antarctica whereas much more common Ptychopteridae are not discovered in Australia and South America.

No distribution maps have previously been published for either of the two families, and no species lists have been compiled since the excellent monograph by Peus [1958]. The comparison of data for distribution of two families in the past and the present is the subject of our study.

\section{Material and methods}

Species lists (Appendices 1, 2) and maps (Figs 1-4) were compiled based on own and literature sources, supplemented by unpublished data obtained from several experts (details see below). Figure 1 shows all the fossil records known to us, including yet undescribed specimens, not included in the species lists: ptychopterids from the Upper Triassic of Germany [Barth et al., 2011] and the Lower Cretaceous of Spain, Transbaikalia, and Mongolia [pers. obs.], as well as tanyderids from the Lower Cretaceous of England [Coram \& Jarzembowski, 1998], Spain [A. Arillo, pers. comm.], Brazil [J. Ansorge, pers. comm.] and Upper Cretaceous of Taimyr [pers.obs.]. A specimen of uncertain systematic position from the Upper Triassic Cow Branch Formation of eastern USA [Krzemiński, 1992], is excluded from the list of extinct Ptychopteridae (Appendix 1) as it may actually represent Nadipteridae [Shcherbakov et al., 1995]. The monotypic Mesozoic genus Bolboia Kalugina, 1989, known from a larva found at a single Jurassic locality in Transbaikalia and tentatively placed in Ptychopteridae, is present on the map, but omitted from the list because it may be a synonym of Eoptychopterina Kalugina, 1985 [Kalugina, 1989; Lukashevich, 2008]. The monotypic genus Sinoptychopterites Hong, 2002 from Eocene Fushun amber [Hong, 2002] was not considered either, because it is known only from a male that undoubtedly does not belong to Ptychopteridae, as indicated by the presence of ocelli, short antennae, short maxillary palps, and the absence of large labella; its familial affinity cannot be determined without re-examination of the type specimen. The formal genus "Tanyderites" Kalugina, 1985 from the Jurassic deposits of Siberia was described with doubts about its familial placement [Kalugina, Kovalev, 1985], we consider these doubts justified and it is omitted from the list (Appendix 2). The species diversity of Mesozoic Ptychopteridae and Tanyderidae - particularly those described from Jurassic deposits of China - may be somewhat exaggerated due to over-splitting, but this is of no consequence for the present study since all the species included undoubtedly belong to that family.

The maps of modern distribution (Figs 2-3) are based on original species descriptions, supplemented by data from catalogues [Alexander, 1965; Hutson, 1980; Oosterbroek, 1989] and other sources [Alexander, 1936; Wood, 1952; Freeman, 1959; Tjeden, 1960; Exner, Craig, 1976; Zwick, 1988; Krzemiński, Zwick, 1993; Stubbs, 1993; Koç, Barlas, 2002; Nakamura, Saigusa, 2009; Ujvárosi et al., 2011; Andersen et al., 2013; Kang et al., 2013; Paramonov, 2013; Fasbender, Courtney, in press]. For rare species, all known recent localities were mapped, which often amounted to the type locality only. For widely distributed species, only selected localities were mapped, chosen with the purpose of representing modern ranges of Ptychopteridae and Tanyderidae as completely as possible;

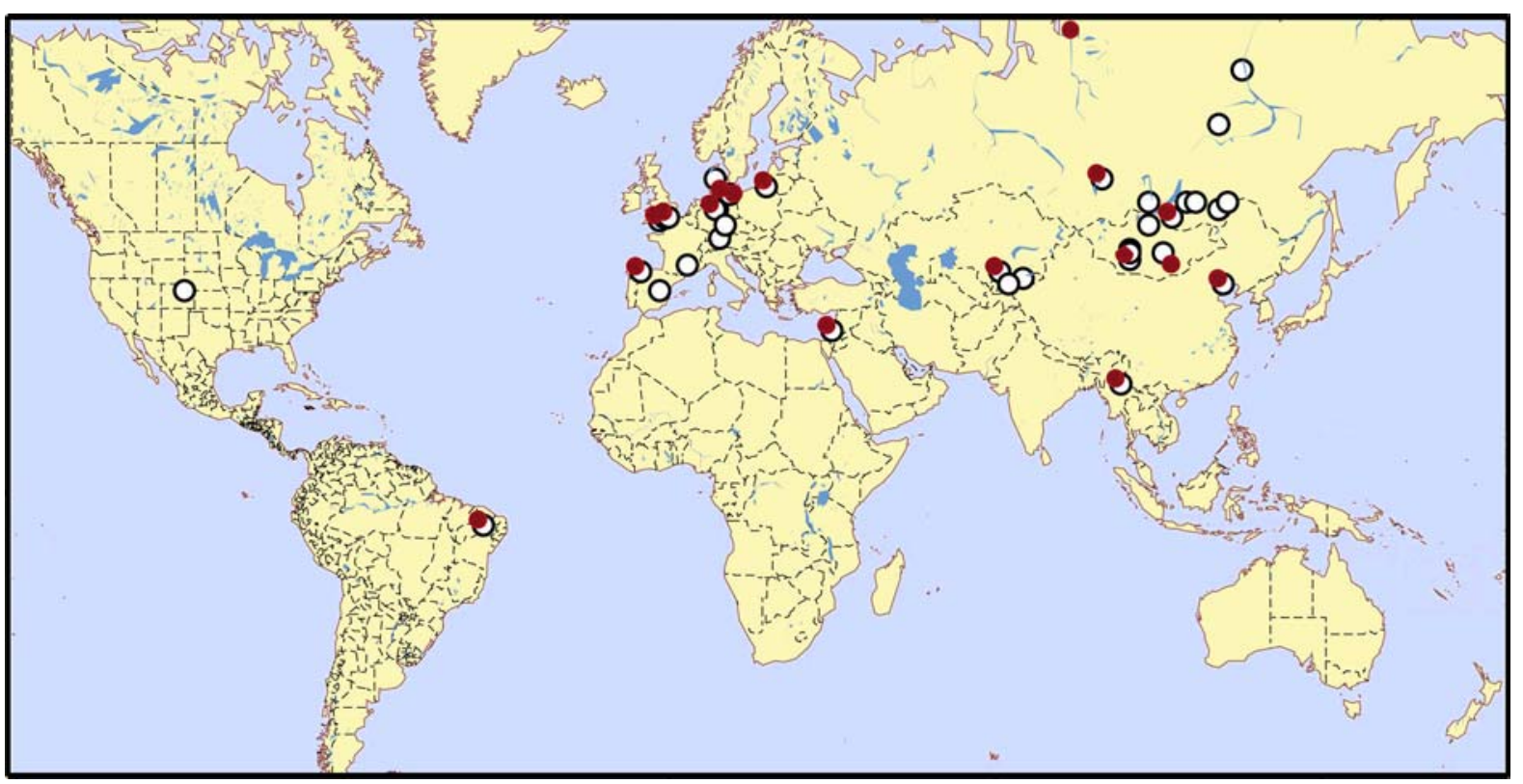

Fig. 1. Distribution map of extinct Ptychopteridae (open circles) and Tanyderidae (closed circles).

Рис. 1. Распространение вымерших Ptychopteridae (незакрашенные кружки) и Tanyderidae (закрашенные кружки). 
some unpublished records were also included [P. Zwick, pers. comm.; N. Paramonov, pers. comm.; M. Chertoprud, pers. comm.].

The classification of biogeographical regions accepted here follows Emeljanov [1974, 2013]; in particular, the northern limit of the Indo-Malayan region is drawn along the southern slopes of the Himalayas, at 2,500 m.a.s.l., and southernmost China, with only the southern part of the Yunnan province, most of the provinces Guangxi and Guangdong, and the islands of Taiwan and Ryukyu included.
The climate classification system accepted here follows Alisov [1964]; in particular, the subtropical zone is a separate one and the subarctic zone is located along the Arctic Circle, generally at latitudes from $60^{\circ}$ to $70^{\circ} \mathrm{N}$ with the boreal forests of Alaska, Canada and Siberia included partially.

The paleogeographical reconstructions accepted here follow Blakey [2008].

The maps were generated using the Map-It program at http://woodshole.er.usgs.gov/mapit.

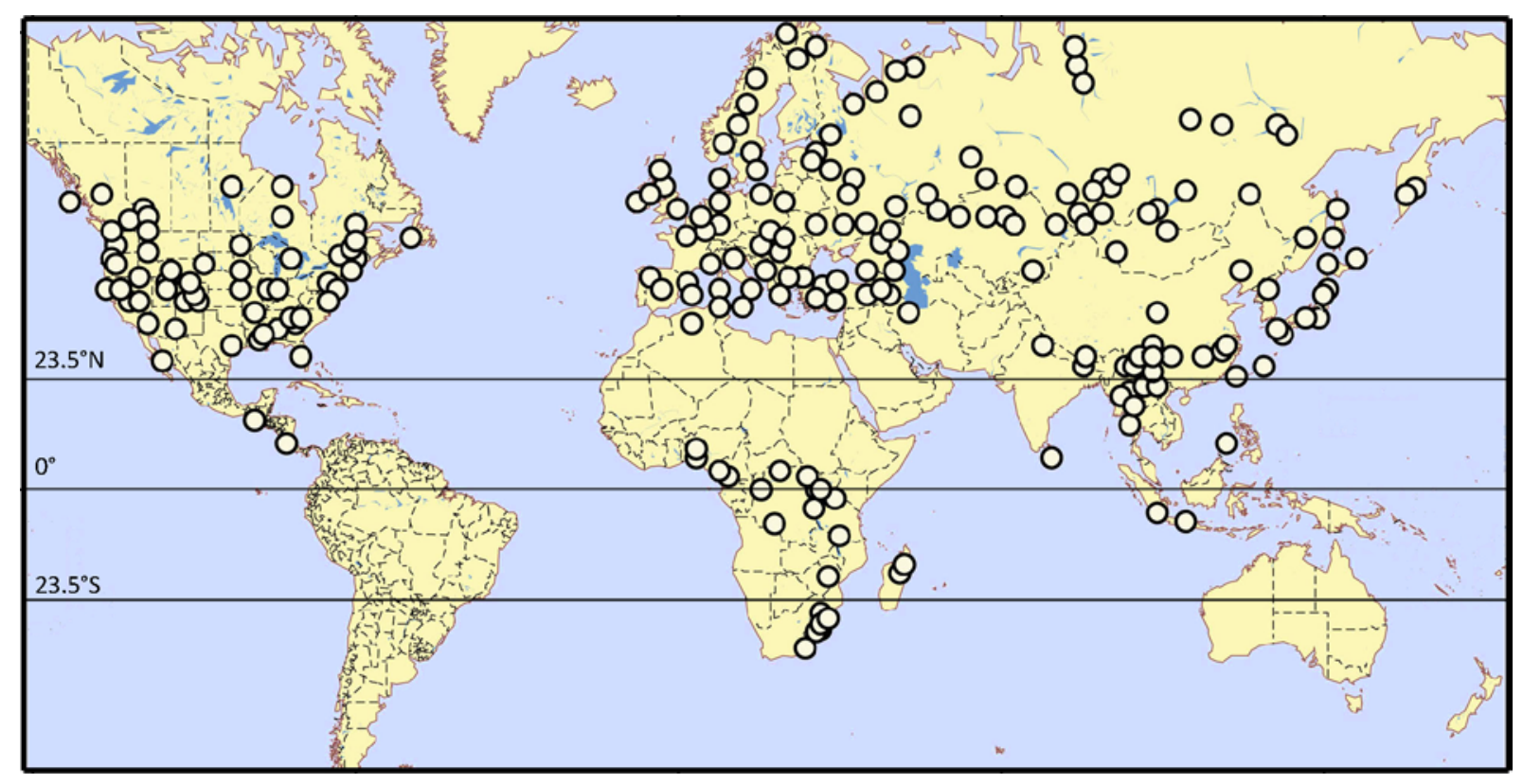

Fig. 2. Distribution map of extant Ptychopteridae.

Рис. 2. Распространение современных Ptychopteridae.

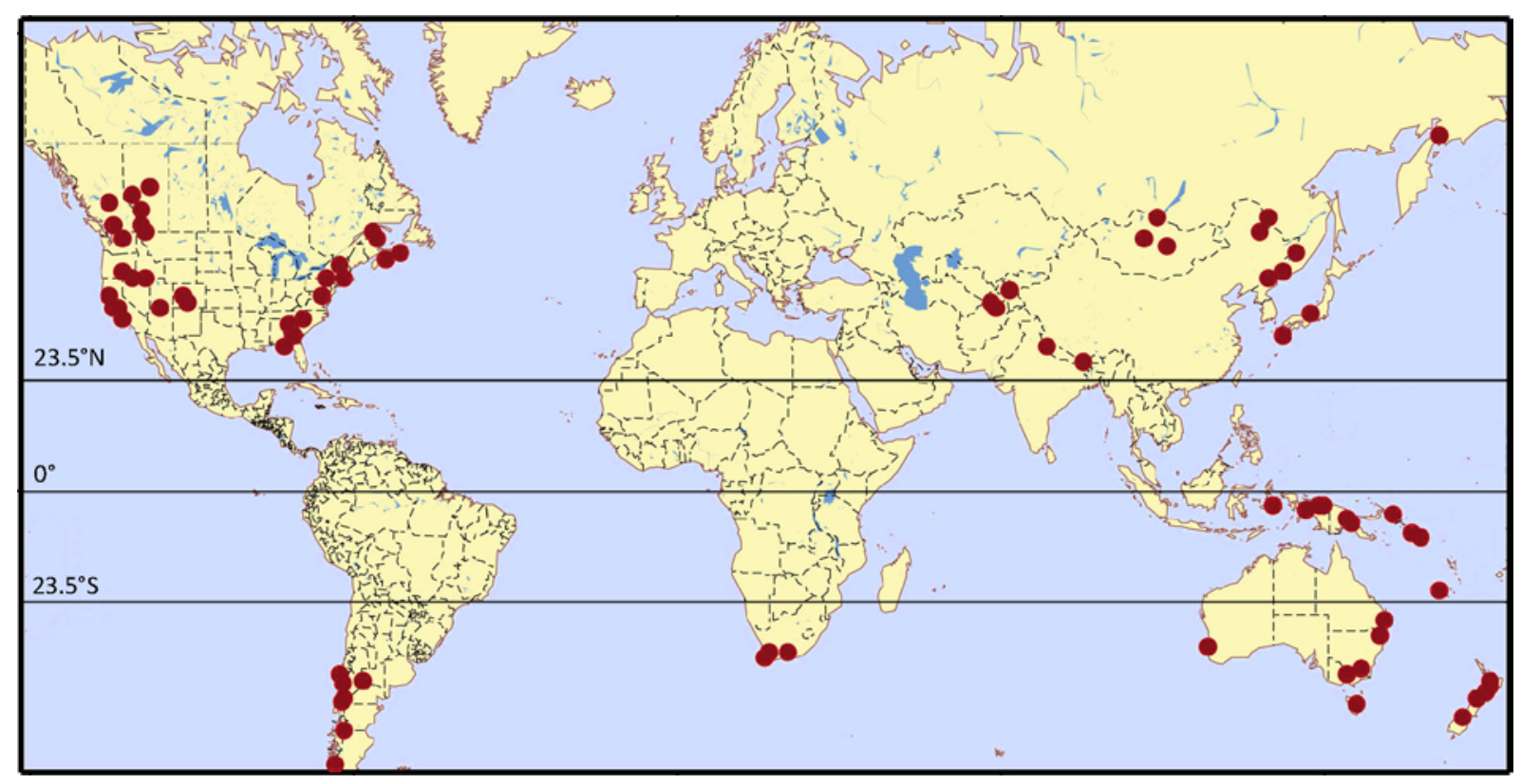

Fig. 3. Distribution map of extant Tanyderidae.

Рис. 3. Распространение современных Tanyderidae. 


\section{Results}

Distribution of extinct

Ptychopteridae and Tanyderidae

Most fossils (Jurassic - exclusively) have been discovered in Eurasia, with few specimens found in North or South America, while neither extinct ptychopterids nor tanyderids have yet been found in Africa or Australia (Figs 1,4). This is more likely to reflect the collecting bias than actual distribution of these families in the past: outside of Eurasia, the few Mesozoic dipterans are known [Schlüter, 2003; Lara \& Lukashevich, 2013], with Jurassic ones being described only from Australia yet and their investigation being in the very beginning [Oberprieler, Yeates, 2014].

Both families are represented in the Lower, Middle, and Upper Jurassic, as well as Lower Cretaceous, Eocene and Miocene deposits of Laurasia (Europe, Central Asia, Siberia, China, and North America) and in Cretaceous amber of Myanmar. On the Gondwanan continents, both families have so far been found only in two well-studied and rich Lower Cretaceous localities: Lebanese amber and Brazilian deposits [Lukashevich, Azar, 2003; Krzemiński et al., 2013; Krzemiński et al., 2015]. It should be noticed that Lebanon corresponds to the very edge of Gondwana, the southern shore of Tethys; the fauna of Lebanese amber is distinct from poorly known Gondwanan faunas of similar age and highly similar to those of Cretaceous amber from the southern shore of Laurasia (Spain, France) and Myanmar [Malak et al., 2013; Pérez-de la Fuente et al., 2011; Peris et al., 2014a; Peris, Delclòs, 2015]. At the time of Burmese amber origin (boundary Early/Late Cretaceous) Myanmar had probably been an isolated microcontinent, separate from Laurasia yet, however the time when smaller terranes around Indochina-East Malaya-Sibumasu were accreted is unclear, as is their origin, and some are suggested to have come from Asia and others from Australia [Hall, 2012].

As one can see, both families have been recorded in all sufficiently well-studied Cretaceous faunas of the equatorial zone: Lebanese and Burmese amber and Santana deposits of Brazil. In contrast, neither was found in the Cenozoic equatorial localities, which display fossil faunas of the modern tropical type: Miocene Dominican and Mexican amber and Miocene-to-Pliocene amber of Sumatra, Borneo, and Philippines. The Dominican amber has been studied so thoroughly that the lack of records clearly must indicate the absence of these families from the fauna. On the other hand, Tanyderidae and the ptychopterid subfamily Bittacomorphinae, neither currently occurring in Europe, both occurred there as recently as the Cenozoic and have their youngest European records from Eocene Baltic amber and the Late Miocene of France, respectively [Alexander, 1931; Podenas, 1997; Krzemiński et al., 2012].

Nearly all Mesozoic and Paleogene tanyderids have been found along with ptychopterids, although by no means at every ptychopterid locality (Fig. 1), so throughout most of their histories they co-occurred on the same territories (at least in Eurasia). This suggests that the two families had similar preferences with respect to terrains and climates and partitioned ecological niches at a more subtle level. For example, based on their modern preferences, one may suggest that also in the Mesozoic the larvae of Ptychopteridae were associated with riparian saturated mud or detritus-laden water [Alexander, 1927] while those of Tanyderidae were associated with flowing water, cobbles or submerged logs [Lukashevich, Shcherbakov, 2014]. In the late Mesozoic, just as now, ptychopterids have been distributed much more widely, probably due to their higher tolerance to some environmental factors, such, for example, as eutrophication and low oxygen content of the water.

\section{Distribution of extant}

Ptychopteridae and Tanyderidae

Modern ranges of the two families are mainly associated with subtropical and temperate climates (Figs 2-3). Both families also occur in the subarctic zone (ptychopterids - even beyond the Arctic Circle) and the "astronomical tropics" (between latitudes $23.5^{\circ} \mathrm{N}$ and $23.5^{\circ} \mathrm{S}$ ), however their tropical distribution is clearly associated with montane areas showing distinct vertical stratification: in the Neotropics, these are the montane areas of the Central-American Isthmus; in the Afrotropics, mountains of East Africa and Cameroon and the mountainous East of Madagascar; in the Indo-Malayan region, mountains of the western Indo-China, Sunda Islands, and Ceylon; and in the Australasia, these are New Guinea and adjacent mountainous islands. This is precisely how ptychopterids are usually characterized: "The family is generally characteristic of cooler, usually temperate or higher-altitude areas of the world" [Hancock, 2009] or "...the records for all the Subsaharan Ptychoptera species show that montane forest (including gallery forest) is the preferred habitat, and my experiences of collecting Ptychoptera in Madagascar are that the species there similarly occur in such a habitat" [Stuckenberg, 1983]. All the records of ptychopterids out of subtropical climate and warmer areas of temperate climates, namely in the subarctic zone and in boreal forests of temperate zone with sharp temperature fluctuations across the seasons (Canada, Siberia, and Lapland) as well as in lowlands of the equatorial and subequatorial zones (Niger and Congo basins) belong to widely distributed species, common, respectively, in broad-leaved forests of Europe and North America and subtropical mountains of Africa. To the best of our knowledge, this family shows no endemism neither in taiga nor tundra, nor lowland equatorial rainforest even at the species level. For example, the common European species Ptychoptera minuta Tonnior, 1919 and P. contaminata (Linnaeus, 1758) occur in taiga and tundra, reaching Finnmark in the northermost Norway and Yenisei Gulf and Yakutia in Russia [Krzemiński \& Zwick, 1993; Andersen et al., 2013; N. Paramonov, pers. comm.]. The African species $P$. uelensis Alexander, 1928 and $P$. africana Alexander, 1920, widely occurring (occasional- 
ly together) in montane forests of the DR Congo, Burundi, Uganda, and Zimbabwe, have been recorded in gallery forest of Angola and lowland parts of the Congo and Niger basins [Freeman, 1959; Alexander, 1963]. The commonest American species, Bittacomorpha clavipes
(Fabricus, 1781), which is widely distributed in mid and eastern North America, also occurs in boreal forests of Newfoundland and Quebec [Alexander, 1916] and the montane areas of tropical Costa Rica [Fasbender \& Courtney, in press].

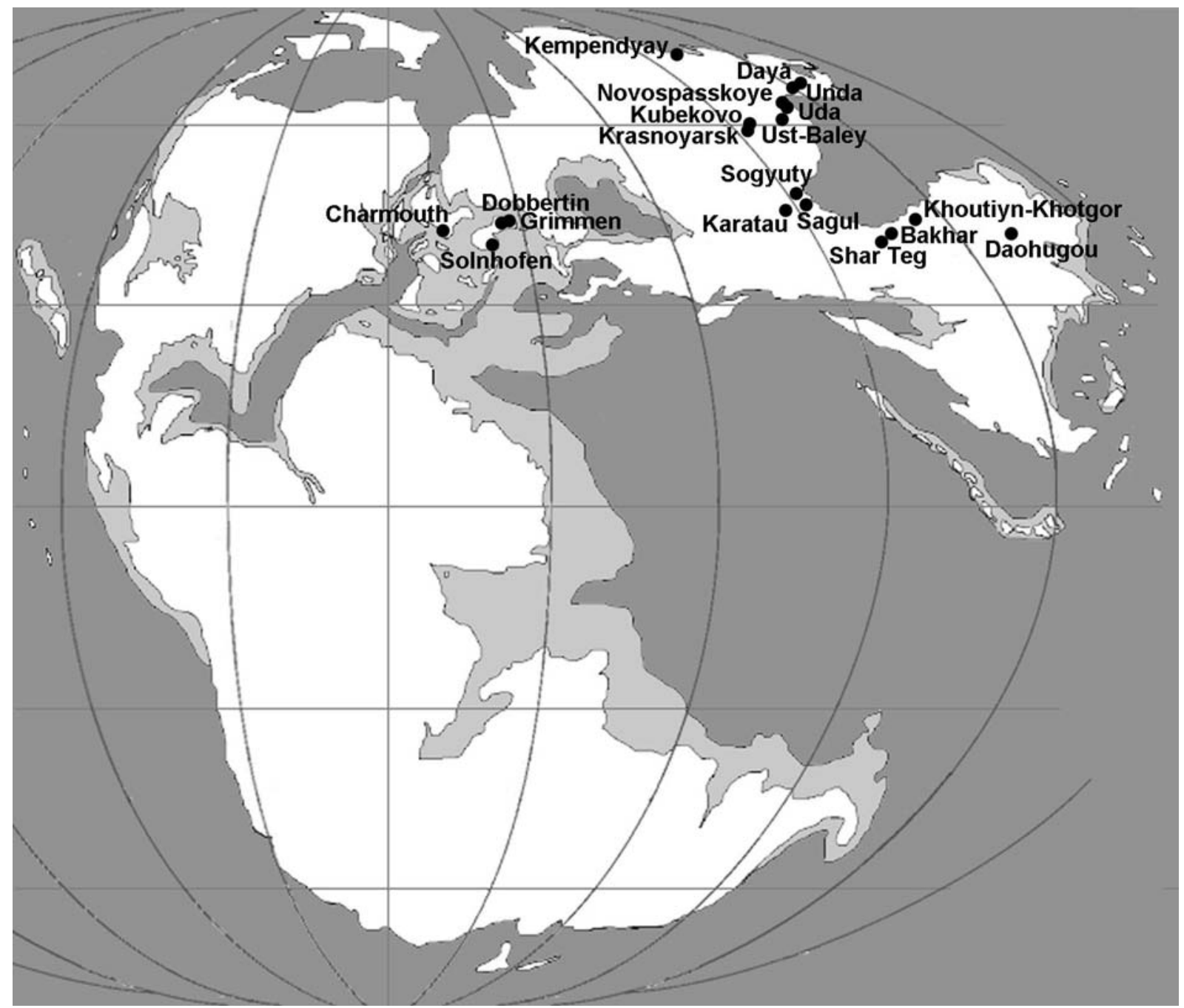

Fig. 4. Jurassic localities of Ptychopteridae and Tanyderidae shown on a paleogeographic map (Middle Jurassic, 170 Ma; redrawn from Blakey, 2011). Charmouth, Great Britain (Sinemurian): ?Eoptychoptera spectra; Nannotanyderus oliviae. Sogyuty, Kyrgyzstan (Sinemurian): Architendipes tshernovskiyi, Eoptychoptera aequidistans, E. vitrea. Dobbertin, Grimmen and others, Germany (Toarcian): Crenoptychoptera dobbertinensis, Eoptychoptera eximia, E. simplex; Nannotanyderus grimmenensis, N. krzeminskii, Praemacrochile decipiens, P. dobbertinensis. Ust-Baley, Transbaikalia (Toarcian): Crenoptychoptera conspecta. Krasnoyarsk, Siberia ( $\left.\mathrm{J}_{1}\right)$ : Crenoptychoptera sp., Proptychopterina makarova. Sagul, Kyrgyzstan $\left(\mathrm{J}_{1}-\mathrm{J}_{2}\right)$ : Eoptychoptera shurabica. Novospasskoye, Transbaikalia $\left(\mathrm{J}_{1}-\mathrm{J}_{2}\right)$ : Eoptychopterina rohdendorphi; Praemacrochile stackelbergi. Kubekovo, Siberia (Aalenian-Bathonian): Crenoptychoptera antica, C. defossa, Eoptychoptera maxima, E. modica, E. paramaculata, Eoptychopterina glabra, Proptychopterina amota, P. handlirschi, P. yeniseica; Protanyderus invalidus. Daohugou, China (Callovian-Oxfordian): Eoptychoptera ansorgei, E. jurassica, Eoptychopterina adnexa, E. antica, E. elenae, E. gigantea, E. mediata, E. postica, Proptychopterina opinata; Praemacrochile ansorgei, P. dryasis, P. chinensis, P. ovalum, Protanyderus astictum, P. vulcanium. Karatau, Kazakhstan (Callovian-Kimmeridgian): Eoptychoptera asiatica, E. aucta, E. magna, Eoptychopterina angularis, E. karatavica, E. omissa, Nedoptychoptera karatavica, Proptychopterina evecta, P. gracilis; Nannotanyderus kubekoviensis, Praemacrochile ansorgei, P. kaluginae, Protanyderus savtchenkoi. Bakhar, Mongolia $\left(\mathrm{J}_{2}-\mathrm{J}_{3}\right)$ : Eoptychoptera altaica. Uda, Transbaikalia $\left(\mathrm{J}_{2}-\mathrm{J}_{3}\right)$ : Eoptychopterina transbaikalica. Solnhofen, Germany (Titonian): Crenoptychoptera bavarica. Khoutiyn-Khotgor, Mongolia $\left(\mathrm{J}_{3}\right)$ : Proptychopterina mongolica. Shar Teg, Mongolia $\left(\mathrm{J}_{3}\right)$ : Crenoptychoptera liturata, Eoptychoptera tempestilla, Eoptychopterina kaluginae, Proptychopterina shartegica; ?Nannotanyderus incertus, Praemacrochile ansorgei, Protanyderus senilis, P. vetus, $P$. nebulosus. Unda, Daya, Transbaikalia $\left(\mathrm{J}_{3}-\mathrm{K}_{1}\right)$ : Eoptychopterina daiensis, E. petri, E. undensis, Proptychopterina oleynikovi. Kempendyay, Siberia $\left(\mathrm{J}_{3}-\mathrm{K}_{1}\right)$ : Crenoptychoptera gronskayae, Eoptychoptera elevata, Proptychopterina immensa, P. tenera.

Рис. 4. Юрские находки Ptychopteridae и Tanyderidae, показанные на палеогеографической карте (средняя юра, 170 млн лет назад, перерисовано из Blakey, 2011). 
With few exceptions, each species occurs within a single biogeographical region. Only three ptychopterid species are known currently from two regions each. Among these, Bittacomorphella zhaotongensis Kang, Wang et Young, 2012 occurs in Yunnan at both sides of the accepted limit of the Indo-Malayan region, Bittacomorphella lini Young et Fang, 2011 has been recorded from Taiwan and Chinese Sichuan [Kang et al., 2012], and only Bittacomorpha clavipes, widely occurring in the Nearctics, also extends into the Neotropics [Fasbender \& Courtney, in press]. A recent surge in the number of descriptions of new ptychopterid species gives hope that, as the limits of the family expand, its distribution will become better known globally and, in particular, along the northern border of the Indo-Malayan region, where numerous species occur. For example, Ptychoptera sikkimensis Alexander, 1963 was formally classified in this study as Palearctic only because its single known specimen had been collected at approximately 3,000 m.a.s.1., and Protanyderus sikkimensis Alexander, 1960 as Indo-Malayan because it had been collected in the same area at the altitude below 2,000 m.a.s.l. However it is likely that both species don't recognize these conventional boundaries.

The actual modern ranges of Ptychopteridae and Tanyderidae are very different. The first family is particular diverse in the Palearctics and the second in Australasia. The first family is associated with Alfred Wallace's "Arctogaea" (the Holarctic, Afrotropical, and Indo-Malayan zoogeographical regions) and common in the Paleotropical region (Fig. 2, Appendix 1). The second displays an essentially amphitropical distribution, perfectly distinct in the western hemisphere and less so in the eastern hemisphere, where a few species additionally extend into the Paleotropics along the mountains of New Guinea and adjacent islands (Fig. 3, Appendix 2). Moreover, the part of the tanyderid range confined to the southern hemisphere (South Africa, Australia, New Zealand, and southernmost South America) gives an impression of a classic "Gondwanan range," i.e. the one representing remnants of the originally continuous Mesozoic biota of Gondwana having survived on its fragments, which have drifted apart after the breakup [Brundin, 1966].

\section{Discussion}

History of the modern ranges of Ptychopteridae and Tanyderidae: the puzzle

Since both families - including even some extant genera - are certainly of the Mesozoic age, their modern ranges are expected to reflect in some ways the paleogeography of the Mesozoic, e.g. the northern continents becoming isolated from the southern ones by the Tethys Sea and the southern continents being continuous as parts of Gondwana. From the fossil record it would be logical to expect both families to be associated mostly with northern continents. Indeed, the modern distribution of Ptychopteridae (Fig. 2) fits those expec- tations ideally by including the Holarctic, Afrotropical, and Indo-Malayan regions (Arctogaea), with a complete absence of records from Australia with New Guinea and New Zealand with adjacent islands (Notogaea), as well as from South America (Neogaea, except its northernmost part, where a few species occur in Costa Rica and southern Mexico). Until its discovery in the Early Cretaceous of Brazil, the family was considered to be of undoubtedly Holarctic origin [Wagner et al., 2008]. It is now obvious that Ptychopteridae, "Arctogaeaic" at present, occurred on the territory of Gondwana in the Mesozoic.

However, the modern distribution of Tanyderidae appears to be a mirror image of what might be expected: it is an essentially amphitropical range (Fig. 3). Its part located in the southern hemisphere ideally corresponds to the Austral Kingdom sensu Morrone [2002], including the Andean, Afrotemperate, Neoguinean, Australotemperate, and Neozelandic regions. If the family's fossil history were less well known that part of the range would almost certainly be attributed a "Gondwanan" origin [for numerous examples, see Eskov, 1987, 1992]. In the northern hemisphere, the range of tanyderids is associated with temperate broad-leaved forests and shows the classical "nemoral disjunction:" the Atlantic and Pacific coasts of North America and the Far East of Asia (with ranges of a few species extending along the Himalayas to the mountains of Central Asia). Remarkably, the border between the ranges of Ptychopteridae and Tanyderidae in Australasia matches both Wallace's and Weber's lines [Eskov, Lukashevich, 2013], which separate the Indo-Malayan and Australian zoogeographical regions [Simpson, 1977].

Therefore, modern ranges do not seem easily predictable from fossil data. The difference between the ranges of Ptychopteridae and Tanyderidae suggests that relative positions of Mesozoic continents - since Brundin's time interpreted as the key factor - had less effect on their formation than some other factors. But which ones?

The hypothesis of "zonal stratification"

The origin of amphitropical disjunct ranges, consisting of two isolated parts in the non-tropical regions of both hemispheres, is an old biogeographical puzzle. One solution has been suggested by the paleoentomologist Vladimir Zherikhin, who studied the global replacement of Cretaceous insect faunas by Cenozoic ones and championed the hypothesis that the modern-type tropical biota is relatively young, of the Eocene age [Zherikhin, 1978, 1993, 2002].

Razumovsky [1971] considered tropical forests (megathermal rainforests) of the modern type to have originated in the Early Cenozoic, probably Eocene, but the present consensus holds that this happened considerably earlier, in the Late Cretaceous [for a review, see Morley, 2011]. Dating tropical biota to the Cretaceous age is based on indirect evidence [e.g. molecular clocks, Davis et al., 2005]. At the same time, the oldest known highly diverse complex of fossil leaves - unique among otherwise species-poor Paleocene floras and interpret- 
ed as a tropical rainforest flora - is dated to the Early Paleocene [Johnson, Ellis, 2002; Wing et al., 2009]. Moreover, palynocomplexes of the modern tropical type become most diverse and widespread exactly during the Middle Eocene [Morley, 2011: fig. 1.2]. Remarkably, in spite of the huge amount of new fossil plant material having been discovered since Razumovsky's time, still only two genera currently restricted to the tropics are known from the Cretaceous: the mangrove palm Nypa and Ctenolophon (as pollen); the records of Artocarpus in the Cretaceous of Greenland have not been confirmed [Axelrod, 1984].

As an important point in favor of his hypothesis Zherikhin [1978] considered the fact that the vast majority of insect and plant relict taxa (confirmed to be of the Mesozoic or Early Paleogene age) distinctly avoid biomes with tropical climates, such as equatorial rainforests and savannas. Even if their ranges extend into the equatorial latitudes ("astronomical tropics"), it usually occurs along mountainous systems, where the local climate is significantly different from the true tropical one (with the temperature of the coldest month above $18^{\circ} \mathrm{C}$ ). In contrast, the highest concentration of such relicts is observed precisely in the subtropical and temperate zones of the both hemispheres. Apparently, such biomes as the Nothofagus forests of the southern hemisphere and the Taxodium forests of North America have retained not only a large number of relict taxa, but also the essential structural characters of pre-Neogene ecosystems.

Zherikhin illustrated his hypothesis with some fifty ranges of undoubtedly ancient insect taxa of the family rank and higher. It turned out that, with the only exception of the termite family Mastotermitidae, all these archaic groups occur either outside the true tropics or are represented there by few species, mostly encroaching from the adjacent subtropical regions. As one can see, the ranges of Ptychopteridae and Tanyderidae, discussed herein, could also be illustrations of that hypothesis. A similar pattern has been recently described for other nematoceran Diptera: "we associate information on phylogeny of different groups of Diptera Trichoceridae, Limoniidae/Tipulidae, Anisopodidae, Keroplatidae, Mycetophilidae, Chironomidae, and Canthyloscelidae/Scatopsidae - with [their] distribution to show that basal offshoots of each of these groups have consistently temperate distributions; the "higher" clades being mostly tropical" [Amorim et al., 2014].

Zherikhin surmised that, during the Mesozoic and Early Paleogene, the global climate was significantly more equable than at present: neither analogues of the modern subarctic climate with cold winter have existed then (the opinion shared by most climate experts [Chumakov et al., 1995; Hay, Floegel, 2012]), nor analogues of the modern tropical climate. It is currently believed [Chumakov, 2004] that the climate of equatorial latitudes began acquiring tropical characteristics (temperature/humidity ratio) much earlier, in the Late Cretaceous; yet the contrast of temperatures between the equator, which was then only slightly "warmer" than at present, and high latitudes, where some subtropical groups of animals and plants occurred until the Neogene, was still much less than at present.

That equability was possible due to a different land/ ocean area ratio (the Cretaceous was a thalassocratic epoch) and different configuration of continents, which allowed a more intensive heat transfer between high and low latitudes by ocean currents. The hypothesis of alternation during the history of Earth between two global climate types, one equable and another with a distinct latitudinal stratification, is accepted by many climatologists, paleobotanists, and zoogeographers [e.g. Vakhrameev, 1988; Farrell, 1990; Greenwood \& Wing, 1995; Archibald, Farrell, 2003; Ponomarenko, 2012a, b; reviewed by Fletcher et al., 2014]. Such a transition to the zonal climate occurred during the Eocene; as a result, the Post-Eocene time was marked not so much by global cooling, but rather by redistribution of the same amount of heat between the high and low latitudes. Thus, following the climate transition, relicts of the Cretaceous and Paleogene had better chances of survival in the regions with subtropical climate and warm areas of temperate climates without sharp temperature fluctuation across the seasons, which in the past dominated the planet. This is how the amphitropical ranges originated.

Therefore, although drastically different, the modern ranges of Ptychopteridae and Tanyderidae seem to have originated via a common mechanism. Each is a relict of a broad (possibly cosmopolitan) Mesozoic range, which underwent fragmentation and became limited to the subtropical and temperate regions of both hemispheres following the Cenozoic global climate change. This explains the absence of both families from equatorial faunas of the Neogene, in spite of their presence in all sufficiently well-studied Cretaceous faunas of the equatorial zone. Moreover, we are confident enough to predict that these groups will eventually be discovered in the Mesozoic faunas close to the tropical zone of the time (for example, in Cretaceous amber of New Jersey).

The hypothesis of "circum-Pacific dominoes"

Whatever the origin of an amphitropical range, it may undergo further modifications. For example, to explain the origin of trans-Pacific disjunctions - which are difficult to interpret from the viewpoint of the vicariance biogeography since the Pacific Ocean had existed from the beginning — the model of "circum-Pacific dominoes" has been suggested [Eskov, 1984; Eskov, Golovatch, 1986]. It interprets all kinds of disjunct ranges divided by the Pacific Ocean as successive stages of reduction of an originally amphitropical range, which has originated on circum-Pacific continents via the zonal stratification mechanism of Zherikhin [1978]. The process was illustrated with diagrams representing amphitropical ranges as domino tiles divided at the equator, hence the name of the model [Eskov, 1984: fig.13; Eskov, Golovatch, 1986: fig. 2]. The original taxon's range is hypothesized to include non-tropical areas of South America, Australia, New Zealand, East 
Asia, and North America (as in the relict dragonfly family Petaluridae and the spider infraorder Hypochilomorpha). The subsequent process of extinction may result in such a taxon surviving (1) only in the southern hemisphere (e.g. the hemipterans Peloridiidae, stoneflies Antarctoperlaria); (2) only in the northern hemisphere (e.g. ice crawlers Grylloblattida); (3) in both hemispheres (e.g. the spider family Mecicobothriidae). The range may then undergo further reduction. For example, a range including Australia, New Zealand, and South America may shrink down to one of the following: Australia+New Zealand (spider family Grandungulidae), Australia+South America (dipteran family Perissommatidae), or New Zealand+South America (spider family Mecysmaucheniidae).

In particular, a disappearance of the northern hemisphere part of an amphitropical range produces the illusion of a "Gondwanan origin," e.g. of Perissommatidae, known from Jurassic deposits of Asia [Kalugina \& Kovalev, 1985] or Mecysmaucheniidae, known from Cretaceous amber of France [Saupe, Selden, 2009]. Dozens of insect taxa limited at present to Australia, New Zealand, and South America (plus sometimes South Africa with Madagascar) have been found on northern continents as fossils [Eskov, 1987, 1992], and that number continues to grow [e.g. Diptera: Grimaldi et al., 2002; Amorim, Grimaldi, 2006; Sinclair, Kirk-Spriggs, 2010; Lukashevich, 2011; other Insecta: Sinitshenkova, 2013; Khramov, 2014, Peris et al., 2014b]. This does not mean that the territorial continuity of the southern hemisphere continents during the Mesozoic, particularly of the areas where the southernmost (paleoantarctic) biota currently occurs, did not have any effect on the origin of modern ranges. For Nothofagus, for example, it clearly did, since all the modern as well as numerous fossil records of that genus are restricted to the southern hemisphere: "Despite occasional reports from the Northern Hemisphere there is no reliable evidence that Nothofagus ever existed outside the Southern Hemisphere" [Friis et al., 2011: 492; see also Vakhrameev, 1988; Dutra, Batten, 2000]. However, the formation of the modern disjunct range of Tanyderidae in the southern hemisphere due to extinction of the "connecting links" on the northern continents appears to be much more plausible since the tanyderid faunas currently occurring on Gonwanan fragments do not share in common any genera.

No phylogeny has yet been estimated for Tanyderidae. Although we, therefore, do not have information on the phylogenetic relationships between modern tanyderid faunas of the five fragments of Gondwana (Africa, India, Australia with New Guinea, New Zealand, and South America), we can still argue that they are not closely related based on the fact that they do not share a single genus in common. Such a complete absence of zoogeographical links at the genus level is particularly unusual for the southernmost biota, which generally shows a high degree of both taxonomic and ecological similarity between the territories where it occurs: southeastern Australia, New Zealand, and southernmost South America.
This cohesiveness, common for many groups of plants and invertebrates [for dipteran examples, see Cranston 2005], is convincingly explained by recent (Cenozoic) trans-antarctic floristic and faunistic exchanges: because, prior to the Pliocene, Antarctica did not have a continuous ice shield and was closer to three other fragments of West Gondwana than it is now, it could serve as an efficient "stepping stone" [Howden, 1974; Zwick, 1977; Amorim et al., 2009]. Unless the absence of tanyderid genera common between Australia, New Zealand, and South America results from taxonomic over-splitting or insufficient knowledge, it must indicate either a fast evolution above the species level since the Pliocene (which is highly unlikely given the relictual character of the biota in those areas) or that exchanges of tanyderid species have not been more intensive between parts of Gondwana than between Gondwana and Laurasia, i.e. between Africa and Eurasia, Australia and Eurasia, or between South America and North America. In contrast, in the northern hemisphere, similarities between continental faunas at the genus level are obvious: the range of the genus Protanyderus Handlirsch, 1909, which occurs both in America and Asia, is a classical example of a trans-Pacific disjunction.

The fauna of tanyderids of New Caledonia may be considered as an interesting "control experiment". Plate tectonics reconstructions suggested that New Caledonia, the Lord Howe Island, and New Zealand have once been parts of one microcontinent, which underwent fragmentation during the Cretaceous [for an outline of the geology of New Caledonia, see Cluzel et al., 2012], but the modern climate of New Caledonia, is much closer to that of coastal areas of Australia (except for its South East with cold winters), and New Guinea. The flora of New Caledonia is much closer to that of Australia and New Guinea than that of New Zealand [Takhtajan, 1978; Lowry, 1998], and the New Caledonian fauna provides many similar examples [Eskov, 1984; Cranston, 2005].

The tanyderid genus Mischoderus Handlirsch, 1909, which occurs in New Zealand, is missing from New Caledonia, where instead occurs Radinoderus Handlirsch, 1909 [Hynes, 1993]. The latter genus occurs also in New Guinea with adjacent islands and in Australia, where it is restricted to the middle part of the East Coast and South West, while in the colder South East it is replaced by Eutanyderus Alexander, 1928. In our opinion, this fact indicates that for tanyderids (like for the New Caledonian biota in general) the effect of the region's tectonic history upon the composition of the modern fauna is negligibly small in comparison with the effect of modern climatic and geographical factors.

Examples of a taxa going extinct in the northern hemisphere (on Laurasian continents), but preserving as relicts in the southern one (on Gondwanan continents) are quite numerous, while the opposite cases are rare (e.g., Grylloblattida and the hymenopteran family Xyelidae [Storozhenko, 2002; Lara et al., 2014]). Eskov [1992, 2002] hypothesized that the asymmetry results, among other causes, from a much larger volume of fossil material being collected in Europe and North 
America and predicted that, as the knowledge of fossil insects of southern continents grows, the number of such "Laurasian relicts" will significantly increase. In the most recent years this proved true. Among several localities, the Lower Cretaceous deposits of Brazil (Santana) yielded the largest number of those taxa that at present are endemic to the northern hemisphere, including snakeflies Raphidioptera [Martins-Neto, Vulcano, 1990], the hymenopteran subfamily Proscoliinae [Rasnitsyn, Martinez-Delclòs, 1999] and mayflies Potamanthoidea [McCafferty, 2004]. It was at this locality where Ptychopteridae, currently missing from the South America (i.e. purely "Arctogaeic"), have been recently discovered [Krzemiński et al., 2015].

\section{Conclusion}

Despite their differences, which appear so dramatic, the modern ranges of Ptychopteridae and Tanyderidae have a common background: both are relictual amphitropical ranges, which have formed via the mechanism of "zonal stratification" from a broad (possibly cosmopolitan) Mesozoic range and became limited to the nontropical regions of both hemisphere following the Paleogene global climate change - as is generally expected for widely distributed Mesozoic taxa. The amphitropical ranges later underwent fragmentation and reduction as described by the model of "circum-Pacific dominoes." In particular, the range of Ptychopteridae has almost completely lost its non-Arctogaeic, "Gondwanan" part.

It is important to emphasize that, in the model of "zonal stratification," the acting cause is the global climatic and geographical transition (origin of the modern-type tropics) and, therefore, its effects are partially similar for all taxa affected. In contrast, the model of "circum-Pacific dominoes" concerns evolution of individual taxa (i.e. their extinction in some parts of the original range); this process is essentially random, and its results may strongly differ even between closely related taxa. Correspondingly, the history of one taxon's range can be extrapolated to co-occurring taxa in the first case, but not in the second.

Our hypothesis of the origin of ptychopterid and tanyderid ranges allows several predictions.

(1) We hypothesized that Ptychopteridae had a wide (possibly worldwide) distribution in the Mesozoic but later became extinct from South America and Australia; the absence of Mesozoic records of ptychopterids from those continents is explained by insufficient search. The family was recently discovered in the Cretaceous of Brazil. We predict that Ptychopteridae will be discovered in other taphonomically suitable Mesozoic Gondwanan localities, particularly in Australia.

(2) Neither family will be found in Cenozoic amber formed in tropical climates, i.e. that from the Dominican Republic, Chiapas, and Sunda Islands. In contrast, in Mesozoic amber from the tropical zone and adjacent areas they have already been discovered (Myanmar, Lebanon), and more such discoveries are expected (for exam- ple, in New Jersey). Among Cenozoic amber, the search for these families must focus on the subtropical regions of that time: Sakhalin, Fushun, Paris Basin and Arkansas.

(3) In the absence of an established phylogeny of Tanyderidae, we argued that the tanyderid faunas currently restricted to fragments of Gondwana are not closely related from the fact that, according to the modern classification, they have no shared genera. If future phylogenetic analyses discover among modern tanyderids a monophyletic Gondwanan group, we predict that its fossil representatives will also be found in the northern hemisphere, and that the order of branching within that group will not match the sequence of Gondwana breakup.

ACKNOWLEDGEMENTS. We are deeply indebted to R. Rakitov (Palaeontological Institute RAS, Moscow) for translating the text into English and insightful comments on the early version of manuscript and to D. Shcherbakov (same institution) for valuable discussion. The authors would also like to thank P. Zwick (Schlitz), N. Paramonov (Zoological Institute, St-Petersburg), M. Chertoprud (Moscow State University), A. Fasbender (Iowa State University, Ames), J. Ansorge (Institut für Geographie und Geologie, Greifswald), and A. Arillo (Universidad Complutense, Madrid), for information on unpublished records of extant and extinct Ptychopteridae and Tanyderidae, E. Yan (Paleontological Institute, Moscow) and V. Blagoderov (Natural History Museum, London), for their assistance in obtaining literature, and S. Podenas (Vilnius University) for valuable unpublished information. We thank R. Blakey (Northern Arisona University, Flagstaff) for a kind permission to use his paleogeographical map and two anonymous reviewers for helpful comments on the early version of manuscript.

The study was partly supported by the Russian Foundation for Basic Research, project no.13-04-01839.

\section{References}

Alexander C.P. 1916. New or little-known crane-flies from the United States and Canada: Tipulidae, Ptychopteridae. Diptera, Part 3 // Proceedings of the Academy of Natural Sciences of Philadelphia. Vol.63. P.486-549.

Alexander C.P. 1927. Diptera fam. Tanyderidae // Genera Insectorum. Vol.189. P.1-13.

Alexander C.P. 1931. Crane-flies of the Baltic amber (Diptera) // Bernstein-Forschungen. Vol.2. P.1-135.

Alexander C.P. 1936. The distribution of Tanyderus pictus Ph. (Fam. Tanyderidae, Ord. Diptera) // Revista Chilena de Historia Natural. Vol.39. P.86-87.

Alexander C.P. 1963. The crane flies of Angola (families Ptychopteridae and Tipulidae; Diptera) // Subsidious para o estudo da biologia na Lunda. Lisboa. 44 p.

Alexander C.P. 1965. Family Ptychopteridae // A. Stone, C.W. Sabrosky, W.W. Wirth, R.H. Foote \& J.R. Coulson (eds). A catalog of the Diptera of America north of Mexico. Agriculture Handbook. Vol.276. P.97-98.

Alexander C.P. 1967. The crane flies of California // Bulletin of the California Insect Survey. Vol.8. P.1-269.

Alisov B.P. 1964. Climate zones and areas. Map, scale 1:80,000,000. GUGK, Moscow. Available from http://geochemland.ru/uploads/ images/FGAM/020.jpg. (accessed May 2015) [In Russian].

Amorim D.S., Grimaldi D.A. 2006. Valeseguyidae, a new family of Diptera in the Scatopsoidea, with a new genus in Cretaceous amber from Myanmar// Systematic Entomology. Vol.31. P.508516. 
Amorim D.S, Oliveira S.S., Falaschi R.L., Ribeiro G.C. 2014 Dipterans spreading in time and space - from the Jurassic to the Cretaceous, from temperate to tropical $/ / 8^{\text {th }}$ International Congress of Dipterology, 10-15 August 2014, Potsdam, Germany. Abstract Volume. P.19.

Amorim D.S., Santos C.M.D., Oliveira S.S. 2009. Allochronic taxa as an alternative model to explain circumantarctic disjunctions // Systematic Entomology. Vol.34. P.2-9.

Andersen T., Hagenlund L.K., Haland O., Kvifte G.M., Skartveit J. 2013. New records of lower Diptera ("Nematocera") from Finnmark, northern Norway // Norwegian Journal of Entomology. Vol.60. P.182-189.

Ansorge J. 1994. Tanyderidae and Psychodidae (Insecta: Diptera) from the Lower Jurassic of northeastern Germany // Paläontologische Zeitschrift. Vol.68. No.1-2. P.199-209.

Archibald B., Farrell B.D. 2003. Wheeler's dilemma // Acta zoologica cracovensia. Vol.46. P.17-23.

Axelrod D.I. 1984. An interpretation of Cretaceous and Tertiary biota in Polar regions // Palaeogeography, Palaeoclimatology, Palaeoecology. Vol.45. P.105-147.

Barth G., Ansorge J., Braukmann C. 2011. First record of the genus Ipsvicia (Hemiptera: Ipsviciidae) outside Gondwana - an Australian genus from the Upper Triassic of Germany // Polskie Pismo Entomologiczne. Vol.80. No.4. P.645-657.

Blagoderov V., Grimaldi D.A., Fraser N. 2007. How time flies for flies: diverse Diptera from the Triassic of Virginia and early radiation of the order // American Museum Novitates. No.3572. P. 1-39.

Blakey R.C. 2008. Gondwana paleogeography from assembly to breakup - a 500 m.y. odyssey // C.R. Fielding, T.D. Frank \& J.L Isbell (eds). Resolving the Late Paleozoic Ice Age in Time and Space. Geological Society of America. Special Paper 441. P.1-28.

Blakey R.C. 2011. Library of Paleogeography. http:// cpgeosystems.com/paleomaps.html (accessed April 2015)

Brundin L. 1966. Transantarctic relationships and their significance, as evidenced by chironomid midges with a monograph of the subfamilies Podonominae and Aphroteniinae and the Austral Hertagyiae // Kunglica Svenska Vetenskapsakademiens Handlingar, Fjärde Serien. Vol.11. No.1. P.1-472.

Chumakov N.M. 2004. Climatic zones and climate of the Cretaceous period // Semikhatov M.A. \& Chumakov N.M. (eds.). Climate in the epochs of major biospheric transformations. Transactions of the Geological Institute of the Russian Academy of Sciences. Vol.550. P.105-123 [in Russian].

Chumakov N.M., Zharkov M.A., Herman A.B., Doludenko M.P., Kalandadze N.N., Lebedev E.A., Ponomarenko A.G., Rautian A.S. 1995. Climate belts of the Mid-Cretaceous time // Stratigraphy and Geological Correlation. Vol.3. P.241-260.

Coram R. \& Jarzembowski E.A. 1998. Insect-bearing horizons in the type Purbeck and new Purbeck/Wealden flies (Diptera) // Proceedings of the Dorset Natural History and Archaeological Society. Vol.119 (for 1997). P.135-140.

Cluzel D., Maurizot P., Collot J., Sevin B. 2012. An outline of the geology of New Caledonia; from Permian-Mesozoic Southeast Gondwanaland active margin to Cenozoic obduction and supergene evolution // Episodes. Vol.35. No.1. P.72-86.

Cranston P. 2005. Biogeographic patterns in the evolution of Diptera // D.K.Yeats et B.M. Wiegmann (eds.). Evolutionary biology of Diptera. Columbia University Press, New York. P.274- 311.

Davis C.C., Webb C.O., Wurdack K.J., Jaramillo C.A. \& Donoghue M.J. 2005. Explosive radiation of Malpighiales support a MidCretaceous origin of modern tropical rain forests // The American Naturalist. Vol.165. No.3. E36-E65.

Dong F., Shih C., Ren D. 2015. A new genus of Tanyderidae (Insecta: Diptera) from Myanmar amber, Upper Cretaceous // Cretaceous Research. Vol.54. P.260-265.

Dutra T.L., Batten D.J. 2000. Upper Cretaceous floras of King George Island, West Antarctica, and their palaeoenvironmental and phytogeographic implications // Cretaceous Research. Vol.21. P.181-209.

Emeljanov [Yemel'yanov] A.F. 1974. Proposals on the classification and nomenclature of ranges // Entomological Review. Vol.53. No.3. P.11-26.
Emeljanov A.F. 2013. [Classification of biogeographical regions.] http://www.zin.ru/animalia/coleoptera/rus/bioreg1.htm(accessed May 2015) [in Russian].

Eskov K.Yu. 1984. Continental drift and the problem of historical biogeography // Chernov Yu.I. (ed.). Faunogenez i filotsenogenez(Faunogenesis and Phylocenogenesis). Moscow: Nauka. P.2492 [in Russian].

Eskov K.Yu. 1987. A new archaeid spider (Chelicerata: Araneae: Archaeidae) from the Jurassic of Kazakhstan, with notes on socalled "Gondwanan" ranges of recent taxa // Neues Jahrbuch für Geologie und Paläontologie Abhandlungen. Vol.175. No.1. P. 81-106.

Eskov K.Yu. 1992. Archaeid spiders from Eocene Baltic amber (Chelicerata: Araneae: Archaeidae), with remarks on so called "Gondwanan" ranges of recent taxa // Neues Jahrbuch für Geologie und Paläontologie Abhandlungen. Vol.185. No.3. P. $311-328$.

Eskov K.Yu. 2002. 3.4. Geographical history of insects // Rasnitsyn A.P. \& Quicke D.L.J. (eds.). History of insects. Dordrecht, Boston, London: Kluwer Academic Publishers. P.427-435.

Eskov K.Yu., Golovatch S.I. 1986. On the origin of Trans-Pacific disjunction // Zoologische Jahrbücher. Abteilung für Systematic. Vol.113. No.2. P.265-285.

Eskov K.Yu., Lukashevich E.D. 2013. [Is it possible to predict a modern range from fossil records?] // Systematics of organisms. Its value for biostratigraphy and paleobiogeography. LIX session of The Russian Paleontological Society. St-Petersburg. P.41-42 [in Russian].

Evenhuis N.L. 2015. Catalog of fossil Diptera of the world (version 2.0). http://hbs.bishopmuseum.org./fossilcat (accessed April 2015).

Exner K., Craig D.A. 1976. Larvae of Alberta Tanyderidae (Diptera: Nematocera) // Quaestiones Entomologicae. Vol.12. P.219-237.

Farrell B.F. 1990. Equable climate dynamics // Journal of Atmospheric Sciences. Vol.47. P.2986-2995.

Fasbender A., Courtney G.W. (in press). A revision of Bittacomorphinae with a review of the monophyly of the extant subfamilies of Ptychopteridae (Diptera) // Zootaxa.

Fletcher T.L., Greenwood D.R., Moss P.T., Salisbury S.W. 2014. Paleoclimate of the Late Cretaceous (Cenomanian-Turonian) portion of the Winton Formation, central-western Queensland, Australia: new observations based on CLAMP and bioclimatic analysis // Palaios. Vol.29. P.121-128.

Freeman P. 1959. Diptera. Culicidae subfamily Dixinae, Anisopodidae and Ptychopteridae // Ruwenzori Expedition 1952. British Museum (Natural History). Vol.2. P.37-42.

Friis E.M., Crane P.R., Pedersen K.R. 2011. Early flowers and angiosperm evolution. Cambridge: University press. $596 \mathrm{p}$

Grimaldi D.A., Engel M.S., Nascimbene P.C. 2002. Fossiliferous Cretaceous amber from Myanmar (Burma): its rediscovery, biotic diversity, and paleontological signficance // American Museum Novitates. Vol.3361. P.1-77.

Greenwood D.R., Wing S.L. 1995. Eocene continental climates and latitudinal temperature gradients // Geology. Vol.23. P.10441048.

Hancock E.G. 2009. 23. Ptychopteridae // Brown B.V. et al. (eds.). Manual of Central American Diptera. Vol.1. Ottawa: NRC research Press. P.357-358.

Hall R. 2012. Sundaland and Wallacea: geology, plate tectonics and palaeogeography // Gower D. J, Johnson K. G., Richardson J. E., B.R. Rosen, L. Ruber \& S.T. Williams (eds). Biotic evolution and environmental change in Southeast Asia. New York: Cambridge University Press. P.32-78.

Hay W.H., Floegel S. 2012. New thoughts about the Cretaceous climate and oceans // Earth-Science Reviews. Vol.115. P.262-272.

Hong Y.C. 2002. Amber insects of China. Beijing: Beijing Science and Technology Press. 654 p. [in Chinese]

Howden H.F. 1974. Problems of dispersal of terrestrial organisms in relation of continental drift // Bulletin of American Association of Petroleum Geologists. Vol.58. No.12. P.2497-2501.

Hutson A.M. 1980. 4. Family Ptychopteridae// R.W. Crosskey (ed.). Catalogue of the Diptera of the Afrotropical Region. London: British Museum (Natural History). P.106-107. 
Hynes C.D. 1993. The crane-flies of New Caledonia (Diptera Tanyderidae, Tipulidae) // J. Matile, J. Najt \& S. Tiller (eds.). Zoologia Neocaledonica. Vol.3. Mémoires du Muséeum National d'Histoire Naturella. Vol.157. P.73-121.

Johnson K.R., Ellis B. 2002. A tropical rainforest in Colorado 1.4. million years after the Cretaceous-Tertiary boundary // Science. New Series. Vol.296. No.5577. P.2379-2383.

Kalugina N.S. 1989. [New Psychodomorphic dipteran insects from the Mesozoic of Siberia (Diptera: Eoptychopteridae, Ptychopteridae)] // Paleontologicheskii Zhurnal. No.1. P.65-77 [in Russian].

Kalugina N.S. 1992. [Psychodomorph dipterans from Jurassic of Mongolia (Diptera: Tanyderidae, Eoptychopteridae)] // Paleontologicheskii Zhurnal. No.3. P.110-113 [in Russian].

Kalugina N.S., Kovalev V.G. 1985. [Jurassic Diptera of Siberia]. Moscow: Nauka. 200 p. [in Russian].

Kang Z., Wang J., Yang D. 2012. Species of Bittacomorphella Alexander from China with descriptions of two new species (Diptera: Ptychopteridae) // Zootaxa. Vol.3557. P.31-39.

Kang Z., Yao G., Yang D. 2013. Five new species of Ptychoptera Meigen with a key to species from China (Diptera: Ptychopteridae) // Zootaxa. Vol.3682. P.541-555.

Koç H., Barlas M. 2002. Beiträge zur Ptychopteridenfauna der Türkeu (Diptera: Ptychopteridae) // Studia dipterologica. Vol.9. No.2. P.409-411.

Krzemiński W. 1992. Triassic and Lower stage of Diptera evolution // Mitteilungen der Schweizerischen Entomologischen Gesellschaft. Vol.65. P.39-59.

Krzemiński W., Azar D. \& Skibińska K. 2013. Nannotanyderus ansorgei sp. n., the first member of the family Tanyderidae from Lebanese amber // D. Azar, M. Engel, E. Jarzembowski, L. Krogmann \& J.Santiago-Blay (eds). Insect Evolution in an Amberiferous and Stone Alphabet. Proceedings of the 6th International Congress on Fossil Insects, Arthropods and Amber. P.131-143.

Krzemiński W., Kania I., Lukashevich E. 2015. The first South American record of fossil Eoptychopterinae (Ptychopteridae: Diptera) from the Lower Cretaceous Santana Formation // Cretaceous Research. Vol.52. P.548-555.

Krzemiński W., Kania I., Nel A. 2012. Probittacomorpha brisaci $n$. $s p$. (Ptychopteridae, Bittacomorphinae) from the Late Miocene of Montagne d'Andance, Saint Bauzile, Ardèche (France) // Zootaxa. Vol.3521. P.80-88.

Krzemiński W., Krzemińska E. 2003. Triassic Diptera: descriptions, revisions and phylogenetic relations // Acta Zoologica Cracoviensia. Vol.46. P.153-184

Krzemiński W., Zwick P. 1993. New and little known Ptychopteridae (Diptera) from the Palearctic region // Aquatic Insects. Vol.15. P.65-87.

Khramov A. 2014. [Lacewings of the family Osmylidae (Insecta: Neuroptera) from the Upper Jurassic of Asia] // Paleontologicheskii Zhurnal. No.3. P.77-86 [in Russian, English translation: Paleontological Journal. Vol.48. No.3. P.300-309].

Lara M.B., Lukashevich E.L. 2013. The first Triassic dipteran (Insecta) from South America, with review of Hennigmatidae // Zootaxa. Vol.3710. No.1. P.081-092.

Lara M.B., Rasnitsyn A.P., Zavattieri A.M. 2014. [Potrerilloxyela menendezi gen. et sp. nov. from the Late Triassic of Argentina: the oldest representative of Xyelidae (Hymenoptera: Symphyta) for Americas] // Paleontologicheskii Zhurnal. No.2. P.81-89 [in Russian, English translation: Paleontological Journal. Vol.48. No.3. P.182-190].

Lowry P.P., II 1998. Diversity, endemism and extinction in the flora of New Caledonia: a review // C.I. Peng \& P.P. Lowry II (eds). Rare, threatened, and endangered floras of Asia and the Pacific Rim. Academica Sinica Monograph 16. Taipei: Institute of Botany. P.181-206.

Lukashevich E.D. 2008. [Ptychopteridae (Insecta: Diptera): history of its study and limits of the family] // Paleontologicheski Zhurnal. No.1. P.68-77 [in Russian, English translation: Paleontological Journal. Vol.42. No.1. P.66-74].

Lukashevich E.D. 2011. [New nematocerans (Insecta: Diptera) from the Late Jurassic of Mongolia] // Paleontologicheskii Zhurnal No.6. P.26-33 [in Russian, English translation: Paleontological Journal. Vol.45. No.6. P.620-628].
Lukashevich E.D. 2012. Phylogeny of Ptychopteroidea (Insecta: Diptera) // Paleontologicheskii Zhurnal. No.5. P.32-40 [in Russian, English translation: Paleontological Journal. Vol.46. No.5. P.476-484].

Lukashevich E. D., Azar D. 2003. First Eoptychopteridae (Insecta: Diptera) from Early Cretaceous Lebanese amber // Acta Zoologica Cracoviensia. Vol.46. P.195-204.

Lukashevich E.D., Krzemiński W. 2009. New Jurassic Tanyderidae (Diptera) from Asia with first find of larvae // Zoosymposia. Vol.3. P.155-172.

Lukashevich E.D., Shcherbakov D.E. 2014. First description of Tanyderidae (Diptera) larvae from South America // Russian Entomological Journal. Vol.23. No.2. P.121-138.

Malak M.A., Salamé Y., Azar D. 2013. New phlebotomine flies from Burmese amber (Diptera: Psychodidae: Phlebotominae) // Terrestrial Arthropod Reviews. Vol.6. P.81-101.

Martins-Neto R.G., Vulcano M.A. 1990. Primeiro registo de Raphidioptera (Neuropteroidea) na Formacão Santana (Cretaceo Inferior), Bacia do Araripe, Nordeste do Brasil // Revista Brasileira de Entomologia. Vol.34. No.1. P.241-249.

McCafferty W.P. 2004. Higher classification of the burrowing mayflies (Ephemeroptera: Scapphodonta)//Entomological News. Vol.115. No.2. P.84-92.

Morley R.J. 2011. Cretaceous and Tertiary climate change and the past distribution of megathermal rainforests // M.B. Bush, J.R. Flenley \& W.D. Gosling (eds). Tropical Rainforest Responses to Climatic Change. Berlin, Heidelberg: SpringerVerlag. P.1-34.

Morrone J.J. 2002. Biogeographical regions under track and cladistics scrutiny // Journal of Biogeography. Vol.29. P.149-152.

Nakamura T., Saigusa T. 2009. Taxonomic study of the family Ptychopteridae of Japan (Diptera)//Zoosymposia. Vol.3. P.273303.

Oberprieler S.K, Yeates D.K. 2014. Notoatherix antiqua gen. et sp. nov., first fossil water snipe fly from the Late Jurassic of Australia (Diptera: Athericidae) // Zootaxa. Vol.3866. P.138-144.

Oosterbroek P. 1989. Family Tanyderidae // Evenhuis N. (ed.). Catalog of the Diptera of the Australasian and Oceanian Regions. Honolulu, USA: Bishop Museum Press. P.51-52.

Oosterbroek P., Courtney G. 1995. Phylogeny of the nematocerous families of Diptera (Insecta)// Zoological Journal of the Linnean Society. Vol.115. P.267-311.

Paramonov N.M. 2013. New records of Ptychopteridae (Diptera) from Europe, North Africa and Asia Minor // Studia dipterologica. Vol.20. No.2. P.279-283.

Pérez-de la Fuente R., Delclòs X., Peñalver E., Arillo A. 2011. Biting midges (Diptera: Ceratopogonidae) from the Early Cretaceous El Soplao amber (N Spain) // Cretaceous Research. Vol.32. P.750-761.

Peris D., Chatzimanolis D., Delclòs X. 2014a. Diversity of rove beetles (Coleoptera: Staphylinidae) in Early Cretaceous Spanish amber // Cretaceous Research. Vol.48. P.85-95.

Peris D., Kolibáč J., Delclòs X. 2014b. Cretamerus vulloi gen. et sp.nov., the oldest bark-gnawing beetle (Coleoptera: Trogossitidae) from Cretaceous amber // Journal of Systematic Paleontology. Vol.12. No.7. P.879-891. DOI: 10.1080/14772019.2013.853108

Peris D., Delclòs X. 2015. Fossil Monotomidae (Coleoptera: Polyphaga) from Laurasian Cretaceous amber // Organisms Diversity and Evolution. Vol.15. No.2. P.333-342. DOI 10.1007/s13127015-00205-y

Peus F. 1958 10a. Tanyderidae. 10b. Familie Liriopeidae // E. Lindner (ed.) Die Fliegen der paläarktischen Region. Stuttgart: E.Schweizerbart'sche Verlagsbuchhandlung. 44 p.

Podenas S. 1997. New Macrochile Loew, 1850 (Diptera, Tanyderidae) from Baltic amber // Mitteilungen aus dem GeologischPaläontologischen Institut der Universität Hamburg. Vol.80. P. 73-177.

Ponomarenko A.G. 2012a.[Paleobiography of the Pleistocene: origins of the modern world] // Biogeography: Methodology, Regional and Historical Aspects. Moscow: KMK. P.165-168 [in Russian].

Ponomarenko A.G. 2012b. [Evolution of climate: zonal and equable Earth] // Biogeography: Methodology, Regional and Historical Aspects. Moscow: KMK. P.169-172 [in Russian]. 
Rasnitsyn A.P. \& Martinez-Delclòs X. 1999. New Cretaceous Scoliidae (Vespida=Hemenoptera) from the Lower Cretaceous of Spain and Brazil // Cretaceous Research. Vol.20. P.767-772.

Razumovsky S.M. 1971. [On the origin and age of tropical and laurel-leaved floras] // Bulletin of Moscow Botanical Garden of Academy of Sciences. Vol.82. P.43-51 [in Russian].

Saupe E.E., Selden P.A. 2009. First fossil Mecysmaucheniidae (Arachnida, Chelicerata, Araneae), from Lower Cretaceous (up permost Albian) amber of Charente-Maritime, France // Geodiversitas. Vol.31. P.49-60

Schlüter T. 2003. Fossil insects in Gondwana - localities and palaeodiversity trends // Acta Zoologica Cracoviensia. Vol.46. P.345-371.

Shcherbakov D.E., Lukashevich E.D., Blagoderov V.A. 1995. Triassic Diptera and initial radiation of the order // International Journal of Dipterological Research. Vol.6. P.75-115.

Simpson G.G. 1977. Too many lines; the limits of the Oriental and Australian zoogeographic regions // Proceedings of the American Philosophical Society. Vol.121. No.2. P.107-120.

Sinclair B.J. \& Kirk-Spriggs A.H. 2010. Alavesia Waters and Arilloa Cretaceous-era genus discovered extant on the Brandberg Massif, Namibia (Diptera: Atelestidae) // Systematic Entomology. Vol.35. P.268-276.

Sinitshenkova N.D. 2013. A new stonefly assemblage (Insecta: Perlida=Plecoptera) from the Upper Permian deposits of Northern European Russia // D.S. Aristov, A.S. Bashkuev, V.K. Golubev, A.G. Ponomarenko, A.P. Rasnitsyn, N.D. Sinitshenkova, I.D. Sukatsheva, \& D.V. Vassilenko. Fossil insects of the Middle and Upper Permian of European Russia. Paleontological Journal. Vol.47. No.7. P.766-782.

Skibińska K., Krzemiński W., Coram R.A. 2014. Discovery of the most ancient member of family Tanyderidae (Diptera) from the Lower Jurassic (Sinemurian) of England // Zootaxa. Vol.3857. No. 1. P.125-130.

Storozhenko S.Yu. 2002. 2.2.2.2.1.Order Grylloblattida Walker, 1914 // Rasnitsyn A.P., Quicke D.L.J. (eds.). History of insects Dordrecht, Boston, London: Kluwer Academic Publishers. P.278-281.

Stubbs A.E. 1993. Provisional atlas of the ptychopterid craneflies (Diptera: Ptychopteridae) of Britain and Ireland. Huntingdon: Biological Records Cente. 34 p.

Stuckenberg B.R. 1983. A new species of Ptychoptera (Diptera: Ptychopteridae) from Tongaland // Annales of Natal Museum. Vol.25. No.2. P.437-440.

Takhtajan A.L. 1978. [Floristic regions of the Earth]. Leningrad: Nauka. 248 p. [in Russian].

Tjeden B. 1960. The "phantome crane-fly" in Newfoundland (Dipt. Ptychopteridae)//Opuscula Entomologica. Vol.25. No.1-2.P.145.

Ujvárosi L., Kolsár P.L., Török E. 2011. An annotated list of Ptychopteridae (Insecta, Diptera) from Romania, with notes on the individual variability of Ptychoptera albimana (Fabricius, 1787) // Entomologica romanica. Vol.16. P.39-45.

Vakhrameev V.A. 1988. [Jurassic and Cretaceous floras and climates of the Earth]. Nauka, Moscow. 214 p. [in Russian, translated in English: Vakhrameev V.A. 1991. Jurassic and Cretaceous floras and climates of the Earth. Cambridge University Press, 318 p.]

Wagner R., Barták M., Borkent A., Courtney G., Goddeeris B., Haenni J.-P., Knutson L., Pont A., Rotheray G.E., Rozkošnı R., Sinclair B., Woodley N., Zatwarnicki T., Zwick P. 2008. Global diversity of dipteran families (Insecta Diptera) in freshwater (excluding Simuliidae, Culicidae, Chironomidae, Tipulidae and Tabanidae) // Hydrobiologia. Vol.595. P.489-519.

Wiegmann B.M., Trautwein M.D., Winkler I.S., Barr N.B, Kim J.W., Lambkin C., Bertone A., Cassel B.K., Bayless K.M., Heimberg A.M., Wheeler B.M., Peterson K.J., Pape T., Sinclair B.J., Skevington J.H., Blagoderov V., Caravas J., Kutty S.N., SchmidtOtt U., Kampmeier G.E., Thompson F.C., Grimaldi D.A., Beckenbach A.T., Courtney G.W., Friedrich M., Meier R. \& Yeates D.K. 2011. Episodic radiation in the fly tree of life // Proceedings of the National Academy of Sciences. Vol.108. P.5690-5695.

Wing S.L., Herrere F., Jaramillo C.A., Gómez-Navarro C., Wilf P., Labandeira C.C. 2009. Late Paleocene fossils from the Cerrejón Formation, Colombia, are the earliest record of Neotropical rainforest // PNAS. Vol.106. No.44. P.18627-18632.

Wood H.G. 1952. The crane-flies of the South-West Cape (Diptera, Tipuloidea) // Annals of the South African Museum. Vol.39. P.1-327.

Wood D.M., Borkent A. 1989. Phylogeny and classification of the Nematocera // McAlpine J.F. et al. (eds.). Manual of Nearctic Diptera. Vol.3. Ottawa. P.1333-1370.

Yeates D.K., Wiegmann B.M., Courtney G.W., Meier R., Lambkin C., Pape T. 2007. Phylogeny and systematics of Diptera: two decades of progress and prospects // Zootaxa. Vol.1668. P.565590 .

Zherikchin V.V. 1978. [Development and change of the Cretaceous and Cenozoic faunistic assemblages of Tracheata and Chelicerata] // Transactions of Paleontological Institute AS USSR. Vol.165. P.1-200 [in Russian].

Zherikhin V.V. 1993. [History of the tropical rain-forest biome] // Zhurnal obshchei biologii. Vol.54. No.6. P.659-666. [In Russian].

Zherikhin V.V. 2002. 3.2. Ecological history of terrestrial insects // Rasnitsyn A.P. \& Quicke D.L.J. (eds.). History of insects. Dordrecht, Boston, London: Kluwer Academic Publishers. P.331-388.

Zwick P. 1977. Australian Blephariceridae (Diptera) // Australian Journal of Zoology, suppl. ser. Vol.46. P.1-121.

Zwick P. 1988. Contribution to the Turkish Blephariceridae and Ptychopteridae (Diptera) // Mitteilungen der Schweizerischen Entomologischen Gesellschaft. Vol.61. P.123-129.

\section{Appendix 1. A list of extant and extinct species of Ptychopteridae.}

\section{Extant species}

\section{Palearctics}

Ptychoptera agnes Krzemiński et Zwick, 1993

P. albimana (Fabricius, 1787)

P. alina Krzemiński et Zwick, 1993

P. bellula Alexander, 1937

P. clitellaria Alexander, 1935

$P$. contaminata (Linnaeus, 1758)

$P$. daimio Alexander, 1921

P. delmastroi Zwick et Starý, 2003

P. gutianshana Yang et Chen, 1995

P. handlirschi (Czizek, 1919)

P. helena (Peus, 1958)

P. hugoi Tjeder, 1968

P. ichitai Nakamura et Saigusa, 2009
P. japonica Alexander, 1913

P. kyushuensis Nakamura et Saigusa, 2009

$P$. lacustris Meigen, 1830

P. lii Kang, Yao et Yang, 2013

P. longicauda Tonnior, 1919

P. longwangshana Yang et Chen, 1998

P. minuta Tonnior, 1919

P. obscura (Peus, 1958)

$P$. pallidicostalis Nakamura et Saigusa, 2009

$P$. paludosa Meigen, 1804

P. peusi Joost, 1974

P. qinggouensis Kang, Yao et Yang, 2013

$P$. ressli Theischinger, 1978

P. sikkimensis Alexander, 1963

P. silvicola Zwyrtek et Rozkošný, 1967 
P. scutellaris Meigen, 1818

P. subscutellaris Alexander, 1921

P. surcoufi (Séguy, 1925)

P. takeuchii Tokunaga, 1938

P. wangae Kang, Yao et Yang, 2013

P. xinglongshan Yang, 1996

$P$. yamato Nakamura et Saigusa, 2009

P. yasumatsui Tokunaga, 1939

Bittacomorphella esaki Tokunaga, 1938

B. nipponensis Alexander, 1924

\section{Nearctics}

Ptychoptera byersi Alexander, 1966

P. lenis Osten-Sacken, 1877

P. metallica Walker, 1848

P. minor Alexander, 1920

P. monoensis Alexander, 1947

P. osceola Alexander, 1959

$P$. pendula Alexander, 1937

P. quadrifasciata Say, 1924

P. sculleni Alexander, 1943

P. townesi Alexander, 1943

P. uta Alexander, 1947

Bittacomorpha clavipes (Fabricius, 1781)**

B. occidentalis Aldrich, 1895

Bittacomorphella jonesi (Johnson, 1905)

B. fenderiana Alexander, 1947

B. pacifica Alexander, 1958

B. sackenii (Von Röder, 1890)

\section{Indo-Malaya}

Ptychoptera annandalei Brunetti, 1918

P.bannaensis Kang, Yao et Yang, 2013

P. chalybeata Alexander, 1956

P. distincta Brunetti, 1912

P. formosensis Alexander, 1924

P. gartwalensis Alexander, 1959

P. ichneumonoidea Alexander, 1946

$P$. javensis Alexander, 1937

P. lushuiensis Kang, Yao et Yang, 2013

P. malaisei Alexander, 1946

P. noonadani Paramonov, 2013

$P$. perbona Alexander, 1946

P. persimilis Alexander, 1947

P. praescutellaris Alexander, 1946

P. sumatrensis Alexander, 1936

P. tibialis Brunetti, 1912

Bittacomorphella gongshana Kang, Wang et Yang, 2012

B. lini Young, Fang, 2011*

B. thaiensis Alexander, 1953

B. zhaotongensis Kang, Wang et Yang, 2012*

\section{Neotropics}

Ptychoptera alexanderi Hancock, 2006

\section{Afrotropics}

Ptychoptera africana Alexander, 1920

P. camerounensis Alexander, 1921

P. capensis Alexander, 1917

P. kosiensis Stuckenberg, 1983

P. madagascariensis Alexander, 1937

P. matongoensis Alexander, 1958

P. pauliani Alexander, 1957

P. robinsoni Alexander, 1957

P. uelensis Alexander, 1928

\section{Extinct species}

\section{Palearctics}

Brodilka mitchelli Lukashevich, Coram et Jarzembowski, $2001\left(\mathrm{~K}_{1}\right)$

Ptychoptera deleta Novák, $1877\left(\mathrm{Ng}_{1}\right)$

P. eocenica Podenas, $2007\left(\mathrm{Pg}_{2}\right)$

P. mesozoica Kalugina, $1989\left(\mathrm{~K}_{1}\right)$

Probittacomorpha christenseni Freiwald et Willmann, $1992\left(\mathrm{Pg}_{2}\right)$

P. brisaci Krzemiński, Kania et Nel, $2012\left(\mathrm{Ng}_{1}\right)$

Zhiganka comitans Lukashevich, $1995\left(\mathrm{~K}_{1}\right)$

Z. woolgari Lukashevich, Coram et Jarzembowski, 2001 $\left(\mathrm{K}_{1}\right)$

Proptychopterina amota Lukashevich, $1993\left(\mathrm{~J}_{2}\right)$

P. evecta Lukashevich, $1993\left(\mathrm{~J}_{2-3}\right)$

P. gracilis Lukashevich, $1993\left(\mathrm{~J}_{2-3}\right)$

$P$. handlirschi Kalugina, $1985\left(\mathrm{~J}_{2}\right)^{2-3}$

$P$. immense Lukashevich, $2000\left(\mathrm{~J}_{3}-\mathrm{K}_{1}\right)$

P. makarova Lukashevich, $2000\left(\mathrm{~J}_{1}\right)$

$P$. mongolica Kalugina, $1988\left(\mathrm{~J}_{3}\right)$

P. oleynikovi Kalugina, $1989\left(\mathrm{~J}_{3}-\mathrm{K}_{1}\right)$

P. opinata Lin et Lukashevich, $2006\left(\mathrm{~J}_{2-3}\right)$

$P$. sharategica Kalugina, $1992\left(\mathrm{~J}_{3}\right)$

P. tenera Lukashevich, $2000\left(\mathrm{~J}_{3}-\mathrm{K}_{1}\right)$

P. yeniseica Lukashevich, $1993\left(\mathrm{~J}_{2}\right)$

Architendipes tshernovskiyi Rohdendorf, $1962\left(\mathrm{~J}_{1}\right)$

Crenoptychoptera antica Kalugina, $1985\left(\mathrm{~J}_{2}\right)$

C. bavarica Krzemiński et Ansorge, $1995\left(\mathrm{~J}_{3}\right)$

C. conspecta Lukashevich, $1995\left(\mathrm{~J}_{1}\right)$

C. defossa Kalugina, $1985\left(\mathrm{~J}_{2}\right)$

C. dobbertinensis Ansorge, $1998\left(\mathrm{~J}_{1}\right)$

C. gronskayae Kalugina, $1989\left(\mathrm{~K}_{1}\right)$

C. liturata Lukashevich, $2011\left(\mathrm{~J}_{3}\right)$

Dopychoptera baisica Lukashevich, $1998\left(\mathrm{~K}_{1}\right)$

Eoptychoptera aequidistans Lukashevich, $1998\left(\mathrm{~J}_{1}\right)$

E. altaica (Kalugina, 1988) $\left(\mathrm{J}_{2-3}\right)$

E. ansorgei Ren et Krzemiński, $2002\left(\mathrm{~J}_{2-3}\right)$

E. asiatica (Lukashevich, 1993) $\left(\mathrm{J}_{2-3}\right)$

E. aucta (Lukashevich, 1993) $\left(\mathrm{J}_{2-3}\right)$

E. britannica Lukashevich, Coram et Jarzembowski, 2001 $\left(\mathrm{K}_{1}\right)$

E. cretacea (Kalugina, 1989) $\left(\mathrm{K}_{1}\right)$

E. elevata Lukashevich, $2000\left(\mathrm{~J}_{3}-\mathrm{K}_{1}\right)$

E. eximia (Bode, 1953) $\left(\mathrm{J}_{1}\right)$

E. jurassica Ren et Krzemiński, $2002\left(\mathrm{~J}_{2-3}\right)$

E. longifurcata Lukashevich, Coram et Jarzembowski, $2001\left(\mathrm{~K}_{1}\right)$

E. magna (Lukashevich, 1993) $\left(\mathrm{J}_{2-3}\right)$

E. maxima (Kalugina, 1985) $\left(\mathrm{J}_{2}\right)$

E. modica (Lukashevich, 1993) $\left(\mathrm{J}_{2}\right)$

E. paramaculata (Kalugina, 1985) $\left(\mathrm{J}_{2}\right)$

E. shurabica Lukashevich, $2000\left(\mathrm{~J}_{1}\right)$

E. simplex Handlirsch, $1906\left(\mathrm{~J}_{1}\right)$

?E. spectra (Whalley, 1985) $\left(\mathrm{J}_{1}\right)$

E. tempestilla Lukashevich, $1998\left(\mathrm{~J}_{3}\right)$

E. vitrea Lukashevich, $1998\left(\mathrm{~J}_{1}\right)$

Leptychoptera (L.) dimkina Lukashevich et Azar, 2003 $\left(\mathrm{K}_{1}\right)$

L. (L.) vovkina Lukashevich et Azar, $2003\left(\mathrm{~K}_{1}\right)$

Nedoptychoptera karatavica Lukashevich, $1998\left(\mathrm{~J}_{2-3}\right)$

Eoptychopterina adnexa Hao, Ren et Shih, $2009\left(\mathrm{~J}_{2-3}\right)$

E. angularis Lukashevich, $1993\left(\mathrm{~J}_{2-3}\right)$

E. antica Hao, Ren et Shih, $2009\left(\mathrm{~J}_{2-3}\right)$

E. baisica Kalugina, $1989\left(\mathrm{~K}_{1}\right)$

E. camura Lukashevich, Coram et Jarzembowski, $2001\left(\mathrm{~K}_{1}\right)$ 
E. daiensis Kalugina, $1989\left(\mathrm{~J}_{3}-\mathrm{K}_{1}\right)$

E. demissa Lukashevich, Coram et Jarzembowski, $2001\left(\mathrm{~K}_{1}\right)$

E. dimidiata Lukashevich, Coram et Jarzembowski, 2001 $\left(\mathrm{K}_{1}\right)$

E. elenae Ren et Krzemiński, $2002\left(\mathrm{~J}_{2-3}\right)$

E. gigantea Zhang, $2004\left(\mathrm{~J}_{2-3}\right)$

E. glabra Lukashevich, $1993\left(\mathrm{~J}_{2}\right)$

E. kaluginae Lukashevich, $2004\left(\mathrm{~J}_{3}\right)$

E. karatavica Lukashevich, $1993\left(\mathrm{~J}_{2-3}\right)$

E. mediata Hao, Ren et Shih, $2009\left(\mathrm{~J}_{2-3}\right)$

E. omissa Lukashevich, $2004\left(\mathrm{~J}_{2-3}\right)$

E. petri Lukashevich, $2004\left(\mathrm{~J}_{3}-\mathrm{K}_{1}\right)$

E. postica Liu, Shih et Ren, $2012\left(\mathrm{~J}_{2-3}\right)$

E. rohdendorphi Kalugina, $1985\left(\mathrm{~J}_{-2-2}^{2-3}\right)$

E. transbaicalica Kalugina, $1985\left(\mathrm{~J}_{2-3}\right)$
E. undensis Kalugina, $1989\left(\mathrm{~J}_{3}-\mathrm{K}_{1}\right)$

Nearctics

Ptychoptera miocenica (Cockerell, 1910) $\left(\mathrm{Pg}_{3}\right)$

Indo-Malaya

Leptychoptera (Burmaptychoptera) reburra Lukashevich, $2003\left(\mathrm{~K}_{1-2}\right)$

L. (B.) calva Lukashevich, $2003\left(\mathrm{~K}_{1-2}\right)$

\section{Neotropics}

Eoptychoptera brasiliana Krzemiński, Kania et Lukashevich, $2015\left(\mathrm{~K}_{1}\right)$

* species known also in Palearctics;

** species known also in Neotropics

\section{Appendix 2. A list of extant and extinct species of Tanyderidae.}

\author{
Extant species \\ Palearctics \\ Protanyderus alexanderi Kariya, 1935 \\ P. beckeri (Riedel, 1920) \\ P.esakii Alexander, 1932 \\ $P$. riedeli Savchenko, 1974 \\ P. stackelbergi Savchenko, 1971 \\ P. yankovskyi Alexander, 1938
}

\section{Nearctics}

Protanyderus margarita Alexander, 1948

P. vanduzeei (Alexander, 1918)

P. vipio (Osten-Sacken, 1877)

Protoplasa fitchii Osten-Sacken, 1859

\section{Indo-Malaya}

Protanyderus schmidi Alexander, 1959

P.sikkimensis Alexander, 1960

P.venustipes Alexander, 1960

\section{Neotropics}

Araucoderus gloriosus (Alexander, 1920)

Neoderus patagonicus (Alexander, 1913)

Tanyderus pictus Philippi, 1865

\section{Afrotropics}

Peringueyomyina barnardi Alexander, 1921

\section{Australasia}

Eutanyderus oreonympha Alexander, 1938

E. wilsoni Alexander, 1928

Mischoderus annuliferus (Hutton, 1900)

M. foscipatus (Osten-Sacken, 1880)

M. marginatus (Edwards, 1923)

M.neptunus (Edwards, 1923)

M. varipes (Edwards, 1923)

Nothoderus australiensis (Alexander, 1922)

Radinoderus caledoniana Hynes, 1993

$R$. dorrigensis Alexander, 1930

R. holwayi Alexander, 1946

R. mirabilis (de Meijere, 1915)

R. occidentalis (Alexander, 1925)

R. ochroceratus Colless, 1963

R. oculatus (Riedel, 1921)
R. ornatissimus (Doleschall, 1858)

R. pictipes Alexander, 1946

$R$. solomonis (Alexander, 1924)

R. supernumerarius Alexander, 1953

R. terraereginae (Alexander, 1924)

R. toxopei Alexander, 1959

\section{Extinct species}

\section{Palearctics}

Nannotanyderus ansorgei Krzemiński, Azar et Skibińska, $2013\left(\mathrm{~K}_{1}\right)$

$N$. grimmenensis Ansorge et Krzemiński, $2002\left(\mathrm{~J}_{1}\right)$

$N$. incertus Lukashevich, $2011\left(\mathrm{~J}_{3}\right)$

N. krzeminskii Ansorge, $1994\left(\mathrm{~J}_{1}\right)$

N. kubekovensis Skibińska et Krzemiński, $2013\left(\mathrm{~J}_{2-3}\right)$

N. oliviae Skibińska, Krzemiński et Coram, $2014\left({ }^{2-3}\right)$

Macrochile spectrum Loew, $1850\left(\mathrm{Pg}_{2}\right)$

M. hornei Krzemiński, $2012\left(\mathrm{Pg}_{2}\right)$

Podemacrochile baltica (Podenas, 1997) ( $\left.\mathrm{Pg}_{2}\right)$

Praemacrochile ansorgei Lukashevich et Krzemiński, $2009\left(\mathrm{~J}_{2-3}\right)$

P. chinensis Krzemiński et Ren, $2001\left(\mathrm{~J}_{2-3}\right)$

P. decipiens (Bode, 1953) $\left(\mathrm{J}_{1}\right)$

P. dobbertinensis Ansorge et Krzemiński, $2002\left(\mathrm{~J}_{1}\right)$

$P$. dryasis Dong, Shih, Skibińska, Krzemiński et Ren, $2015\left(\mathrm{~J}_{2-3}\right)$

P. kaluginae Lukashevich et Krzemiński, 2009 ( $\left.\mathrm{J}_{2-3}\right)$

P. ovalum Dong, Shih, Skibińska, Krzemiński et Ren, $2015\left(\mathrm{~J}_{2-3}\right)$

P. stackelbergi Kalugina, $1985\left(\mathrm{~J}_{1-2}\right)$

Protanyderus astictum Dong, Shih, Skibińska, Krzemiński et Ren, $2015\left(\mathrm{~J}_{2-3}\right)$

P. invalidus Lukashevich et Krzemiński, $2009\left(\mathrm{~J}_{2}\right)$

P. mesozoicus Kalugina, $1988\left(\mathrm{~K}_{1}\right)$

P. nebulosus Lukashevich et Krzemiński, 2009 ( $\left.\mathrm{J}_{3}\right)$

P. savtchenkoi Lukashevich et Krzemiński, $2009\left(\mathrm{~J}_{2-3}\right)$

$P$. senilis Kalugina, $1992\left(\mathrm{~J}_{3}\right)$

$P$. vetus Kalugina, $1992\left(\mathrm{~J}_{3}\right)$

P. vulcanium (Zhang, 2004) $\left(\mathrm{J}_{2-3}\right)$

\section{Indo-Malaya}

Dacochile microsoma Poinar et Brown, $2004\left(\mathrm{~K}_{1-2}\right)$ Similinannotanyderus lii Dong, Shih et Ren, $2015\left(\mathrm{~K}_{1-2}\right)$ 